\begin{tabular}{|c|c|c|}
\hline $\begin{array}{l}\text { KULTURA } \\
\text { I } \\
\text { SPOLECZENS }\end{array}$ & $\begin{array}{l}\text { POLSKA AKADEMIA NAUK } \\
\text { KOMITET SOCJOLOGII } \\
\text { INSTYTUT STUDIÓW POLITYCZNYCH } \\
2015, \mathrm{nr} 4\end{array}$ & ISSN 0023-5172 \\
\hline
\end{tabular}

ANDRZEJ ZYBAEA

Szkoła Gtówna Handlowa

\title{
POLITYKA PUBLICZNA W WARUNKACH SOCJOLOGICZNEJ PRÓŻNI
}

Polityka publiczna — rozumiana jako działanie publiczne wykonywane $\mathrm{w}$ rozmyślny sposób - wydaje się jakby z natury zakorzeniona w kulturze danego społeczeństwa, typie relacji społecznych, poziomie kompetencji społecznych (cywilizacyjnych), pewnych doświadczeniach zbiorowych, preferowanych wartościach itp. Zagadnienie zakorzenienia jest od dawna przedmiotem zainteresowania nauk społecznych. Karl Polanyi w znanej książce Wielka transformacja (2010 [1944]) pisał o tym w odniesieniu do gospodarki. Temat kontynuował między innymi Mark Granovetter (1973). Nie jest niczym dziwnym, że polityka publiczna jako dyscyplina wiedzy i określony sposób projektowania działań zbiorowych oraz ich analiza zrodziła się w określonej tradycji kulturowej (anglosaskiej) - pragmatyzmu, empiryzmu i do pewnego stopnia komunitaryzmu.

Bez wielkiego ryzyka można założyć, że działania publiczne prowadzone w różnych warunkach społeczno-kulturowych przynoszą odmienne rezultaty. Potwierdzają to badania Grzegorza Gorzelaka (2000), który przeanalizował działania zrealizowane w kilku społecznościach lokalnych według tego samego wzorca (finansowanie z puli tak zwanych środków przedakcesyjnych). Okazało się, że w niektórych społecznościach nie przyniosły one widocznego po kilku latach efektu (nawet nie było po nich niemal żadnych śladów), a w innych zapoczątkowały pozytywne zmiany w lokalnej gospodarce.

Różne państwa - jako byty osadzone w określonych warunkach kulturowo-socjologicznych - wypracowały odmienne sposoby programowania, re- 
alizowania i ewaluowania działań publicznych. Niektóre mają już bogatą tradycję wykorzystywania mechanizmów ewaluacji (Wielka Brytania, Holandia, Niemcy, Francja, Szwecja). Druga grupa państw - między innymi Irlandia, Belgia, Włochy, Austria - niejako odkryła wartość ewaluacji i zaadaptowała ją jako stały element formułowania działań publicznych. W trzeciej grupie państw nie potrafiono odkryć jej sensu i pozostała biurokratyczną mitręgą (Hiszpania, Portugalia, Grecja). Zdaniem naukowców (Olejniczak, Ferry 2008, s. 25-26), Polska należy do kolejnej grupy — państw, które wprowadzają system ewaluacji działań publicznych, ale czynią to głównie z konieczności. Ewaluacji poddawane są bowiem przede wszystkim działania finansowane $z$ funduszy unijnych (Komisja Europejska narzuciła taki obowiązek).

\section{RAMY KULTUROWE POLITYKI PUBLICZNEJ}

W literaturze przedmiotu odnajdujemy nurty, w których bada się różnego typu uwarunkowania różnicujące narodowe style tworzenia czy uprawiania polityk. Można wyróżnić cztery szkoły, które w odmienny sposób wyjaśniają te odmienności (Adolino, Blake 2001, s. 31-45). Pierwsza z nich tłumaczy je cechami rozwiązań instytucjonalnych przyjętych $\mathrm{w}$ danych państwach, kolejna - cechami systemu demokratycznego (np. system prezydencki versus parlamentarny), następna - możliwościami finansowymi poszczególnych krajów, a ostatnia - cechami kulturowymi danych społeczeństw czy narodów.

Chcę tu zwrócić bliższą uwagę na kwestie kulturowe, a więc skorzystam $z$ dorobku tej szkoły, która odmienność narodowych procesów uprawiania polityk publicznych uzasadnia czynnikami kulturowymi. Przywołam dorobek Francisa G. Castlesa (1998, s. 301), który wprowadził pojęcie krajowego profilu tworzenia polityk publicznych (country policy profile), będącego pochodną tradycji historycznych i kulturowych (tak zwane czynniki długiego trwania). To one w znacznym stopniu przesądzają o tym, że jedne społeczeństwa preferują rozwiązania problemów zbiorowych oparte na działaniach publicznych programowanych bardziej odgórnie, a inne różnorodne działania podejmowane oddolnie przez obywateli czy samoorganizujące się grupy obywateli.

Zdaniem Castlesa, można wyodrębnić profile polityk właściwe dla krajów anglosaskich, niemieckojęzycznych, łacińskich/południowych i skandynawskich. O społeczeństwach anglosaskich mówi się, że są indywidualistyczne, a społeczeństwa skandynawskie - kolektywistyczne (nie ma powodów, aby mylić je ze społeczeństwami odgórnie skolektywizowanymi przez system radziecki). Z kolei kraje łacińskie mają długie tradycje silnego oddolnego poparcia dla działań rządu centralnego.

Społeczeństwa poszczególnych grup krajów mają także odmienne oczekiwania wobec działań publicznych. Na przykład w krajach anglosaskich znaczna część społeczeństwa $z$ nieufnością odnosi się do działań publicznych odgórnie narzucanych przez państwo. Uznaje je za nieefektywne, niedopasowane do 
potrzeb. Potrzeby społeczne lepiej są zaspokajane przez rynek czy mechanizmy samoorganizacji społecznej. Odmienne tendencje łatwo można dostrzec w Europie kontynentalnej. We Francji obywatele bardziej wierzą w zdolność państwa do zaspokajania potrzeb obywateli, rozwiązywania problemów przez działania odgórne. Bywa też, że państwo w znacznie mniejszym stopniu angażowane jest $w$ rozwiązywanie problemów, na przykład $w$ walkę $z$ bezrobociem. Różnice te skutkują odmiennym podejściem w zakresie polityki publicznej. W Wielkiej Brytanii działania publiczne są znacznie bardziej ograniczone niż na przykład we Francji czy w Niemczech.

Jeremy Richardson, Gunnel Gustaffson i Grant Jordan (1982, s. 13) za styl w polityce publicznej uważają pewnego typu „interakcję między podejściem rządzących do rozwiązywania problemów i relacjami między rządem i innymi aktorami w procesie tworzenia polityki". Ich zdaniem odmienne narodowe style projektowania działań publicznych i ich wdrażania są silnie powiązane z normami społecznymi, które legitymizują aktywność publiczną (policy activ$i t y)$, a to $z$ kolei odzwierciedla głęboko zakorzenione wartości respektowane w danych społeczeństwach. Wayne Parsons wyodrębnia cztery typy takich stylów (zob. rys. 1), biorąc pod uwagę następujące cechy działania decydentów:

- antycypacyjność (szeroko rozumiani decydenci działają wyprzedzająco wobec wyłaniających się problemów z uwagi na silną skłonność do ich analizowania, deliberowania itp.),

- reaktywność (decydenci reagują tylko na problemy, które już wystąpiły),

— konsensualność (decydenci starają się uzyskać konsensus z innymi interesariuszami w sprawie swoich projektów działań/interwencji publicznych),

- skłonność do narzucanie rozwiązań danych problemów (decydenci starają się narzucać raczej swoje decyzje innym niż dążyć do konsensusu).

W pierwszym polu widzimy styl tych krajów, w których rządzący — jako podstawowy podmiot działania - planując działania konsultują je, ponieważ dążą do konsensusu, a ponadto starają się analizować problemy, aby móc antycypować ich skutki. Drugiemu polu można przypisać narodowy styl charakteryzujący się inkrementalizmem (model stopniowego działania, „krok po kroku"). Widoczny jest tu pluralizm, ale także fragmentacja oraz reaktywność wobec problemów (np. tzw. gaszenie pożarów, czyli działanie, gdy problem ma postać już zaostrzona). Z kolei trzecie pole obrazuje styl programowania oparty na centralizmie. Rządzący planują działania w sposób odgórny, reaktywny (reagują na problemy, kiedy problem uległ zaostrzeniu), wykazują skłonność do narzucania decyzji pozostałym interesariuszom. W odniesieniu do czwartego pola styl charakteryzuje się tendencją rządzących do planowania działań, racjonalnością, uprzedzaniem zdarzeń, dalekowzrocznością (Parsons 2001, s. 186-187).

Zdaniem Parsonsa w krajach uprzemysłowionych, niezależnie od ich odmienności, rośnie tendencja do formułowania polityk opartych na konsensusie $\mathrm{w}$ ramach tak zwanej społeczności zainteresowanych (policy community), co 
Rysunek 1

Style w programowaniu działań publicznych (policy style)

Decydenci (policy-makers) starają się szukać konsensusu

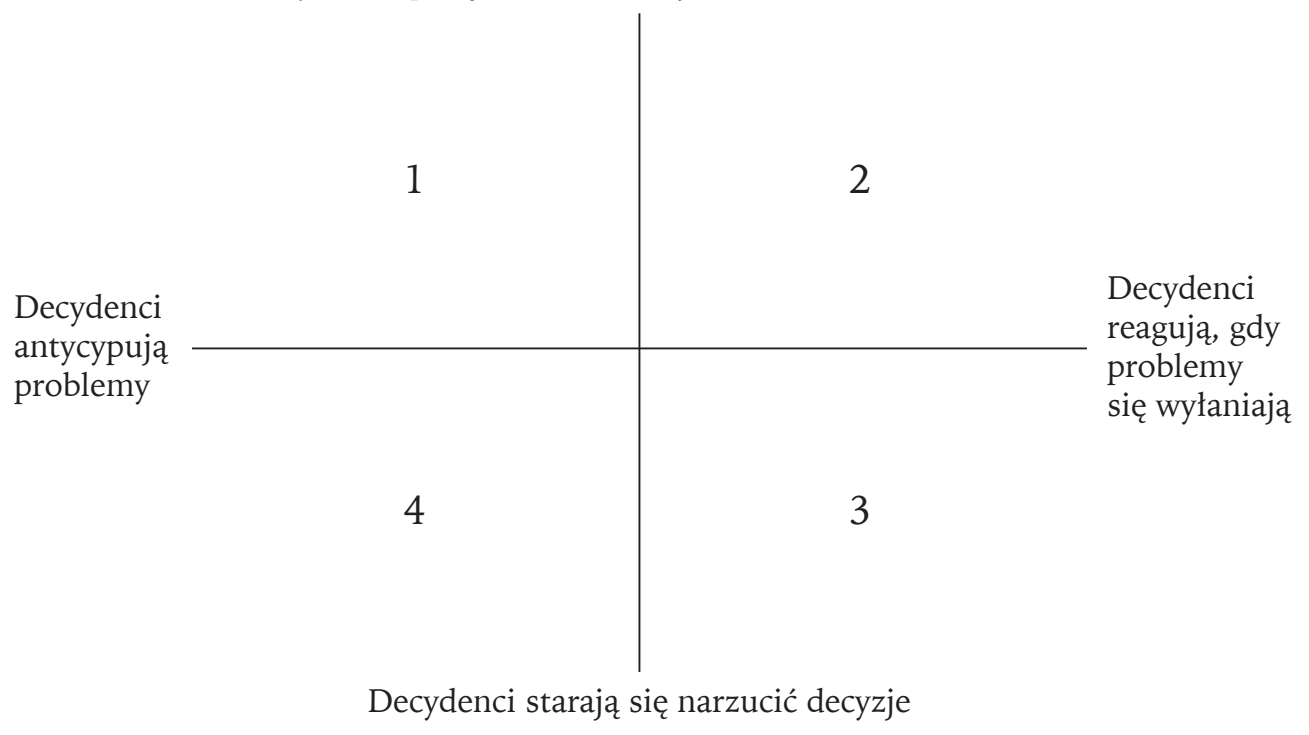

Źródło: Wayne Parsons, Public Policy: An Introduction to the Theory and Practice of Policy Analysis, Aldershot 2001, s. 186.

oznacza większą skłonność do wykorzystywania struktur sieciowych (współpracy interesariuszy). Choć oczywiście nie tracą na znaczeniu interesy grupowe. Są one po prostu lepiej moderowane (Parsons 2005).

Warto także przywołać inny istotny nurt analiz odmienności w procesach formułowania polityk, oparty na dorobku Mary Douglas, brytyjskiej antropolog, i jej teorii kulturowej siatka/grupa (group-grip cultural theory). Wyróżniała ona cztery typy idealne relacji społecznych, biorąc pod uwagę dwa punkty odniesienia - to, jak bardzo jednostki w relacjach społecznych są autonomiczne (w jakim stopniu związane są siatką norm społecznych) oraz $\mathrm{w}$ jakim stopniu podlegają presji decyzji grupowych (są „skolektywizowane”). Są to relacje (Swedlow 2002, s. 269):

— indywidualistyczne (jednostki mają duży zakres autonomii w swoich dążeniach, ale są zdolne do samoorganizacji i zaufania; relacje społeczne są płynne),

— fatalistyczne (zatomizowane jednostki są poddane zarówno wpływom innych, jak i siatce norm społecznych; odczucie, że rzeczywistość jest nieprzewidywalna, a ludzie zwykle niewiarygodni, los przesądza o wszystkim),

- egalitarne (jednostki są autonomiczne, zdolne do współpracy i działania zbiorowego; nacisk na szanse rozwojowe dla wszystkich), 
- hierarchiczne (jednostki są silnie umiejscowione w strukturze społecznej, poddane wpływom innych podmiotów; duża rola mechanizmów kontroli).

Typ relacji społecznych wpływa na to, w jaki sposób aktorzy polityk publicznych (interesariusze) projektują i wykonują działania publiczne, jak diagnozują wyłaniające się problemy. Można założyć, że społeczeństwa o indywidualistycznym typie relacji mogą mieć problem $z$ koordynacją, która jest istotna $\mathrm{w}$ działaniach publicznych. Społeczeństwa hierarchiczne mogą mieć problem z przeprowadzaniem procesu konsultacji i deliberacji nad projektami działań, ponieważ silniejsi interesariusze mogą mieć skłonność do działań jednostronnych. Z kolei w społeczeństwach „fatalistycznych” może istnieć problem z mobilizacją do działań zbiorowych, do diagnozowania problemów, ponieważ istnieje tendencja do niewiary $w$ ich sens i skuteczność.

Analitycy polityk publicznych podchwycili dorobek Douglas, ponieważ uznali, że jej podejście pozwala na stworzenie narzędzia analizy kontekstu kulturowego, w którym przebiega działanie publiczne. Dostrzegają, że jest on istotny, gdyż w znacznym stopniu wpływa na styl podejmowanych działań, a także na ich efektywność.

\section{CHARAKTERYSTYKA POLITYKI PUBLICZNEJ W POLSCE}

W Polsce wciąż dość trudno o charakterystykę działań publicznych (zwłaszcza zweryfikowaną empirycznie). Nie mamy jeszcze zbyt wielkiego dorobku w tym zakresie (zob. Zybała 2013a). Mimo to chciałbym sformułować dość kompleksową hipotezę, według której działania publiczne w Polsce mają następujące cechy wynikające $z$ kontekstu kulturowego:

- częste niskie poczucie odpowiedzialności aktorów działań publicznych za stan i przebieg problemów publicznych (ich poczucie odpowiedzialności jest ograniczone głównie do poziomu mikrostruktur społecznych, czyli do kręgu rodzinnego i koleżeńskiego),

- skłonność do traktowania wielu problemów występujących w przestrzeni publicznej jako problemów „prywatnych” (np. bezrobocie często uznaje się za problem wyłącznie osób bezrobotnych, a nie problem publiczny),

- niewielka skłonność do przeprowadzania zobiektywizowanej analizy problemów zbiorowych, posługiwania się wystudiowanymi metodami analizy, abstrakcjami, typami idealnymi (być może mamy też do czynienia z pewną nieadekwatną kulturą umysłowa),

- preferencje dla wartości indywidualistycznych (umacnianie siebie vs. przekraczanie siebie) i zachowawczych (przystosowanie do status quo vs. otwartość na zmiany) (Ciechiuch 2013, s. 45-64),

- konfrontacyjny charakter relacji między aktorami działań publicznych,

— tendencja do jednostronnych działań ze strony silniejszych interesariuszy (bez odwoływania się do deliberacji i dialogu), 
— niska zdolność do złożonej współpracy między aktorami, a przy tym niedostatek skutecznych mechanizmów moderowania odmienności czy odrębności interesów,

— skłonność do podejmowania działań nieformalnych, w tym także powstawania tzw. brudnych wspólnot, klientelizmu oraz nepotyzmu, określonych form amoralnego familiaryzmu,

- trudności w tworzeniu zobiektywizowanych norm i praw oraz ich respektowaniu w zbiorowości,

— niski poziom uczestnictwa społeczeństwa $\mathrm{w}$ działaniach publicznych (często wynika to $z$ niskiego poczucia podmiotowości w życiu publicznym); niski poziom uspołecznienia procesu decyzyjnego.

Powyższe cechy modelu działania publicznego uznaję za skutek specyficznego typu relacji (więzi) społecznych, które powstały u nas w procesach długiego trwania, a także w wyniku ukształtowania się specyficznego typu uspołecznienia (socjalizacji). Za kluczowe dla zrozumienia tych procesów uznaję twierdzenia Stefana Nowaka dotyczące tak zwanej próżni (pustki) socjologicznej. Uczony ten na podstawie badań empirycznych ustalił, że w Polsce mamy do czynienia $z$ dominacją mikrorelacji (więzi rodzinnych i wąskiego kręgu koleżeńskiego) czy szczególną ich siłą, czemu towarzyszy słabość makrorelacji (więzi między członkami szerszych społeczności). Zagadnienie to ma bogatą literaturę na świecie. Mark Granovetter (1973, s. 1360) napisał kluczowy tekst na ten temat. Wskazał, iż niezwykle trudno jest precyzyjnie wyjaśnić zależności między typem mikrorelacji a kształtem relacji ludzkich w skali makro. Był jednak przekonany, że makrorelacje warunkowane są typem mikrorelacji. Dodatkowym niezwykle trudnym zadaniem jest wyjaśnienie wpływu określonego typu makrorelacji na typ działań, które ludzie podejmują w sferze publicznej.

Diagnoza Nowaka oznacza, że Polacy najchętniej i najefektywniej funkcjonują $\mathrm{w}$ takich mikrostrukturach. Relacje istniejące $\mathrm{w}$ ich obrębie są najbardziej wiążące $\mathrm{w}$ tym sensie, że rodzą poczucie zobowiązania i odpowiedzialności (wytwarzają reguły wiążące, które ograniczają dowolność zachowań wobec drugich). Nowak (1979, s. 160) pisze: „pomiędzy poziomem grup pierwotnych a poziomem narodowej społeczności istnieje - z punktu widzenia identyfikacji ludzi i ich emocjonalnego zaangażowania — rodzaj próżni socjologicznej". Dodaje: „Gdybyśmy chcieli naszkicować gigantyczny "socjogram» oparty na ludzkich poczuciach grupowej więzi i identyfikacji, to tak pojęta społeczna struktura naszego kraju jawiłaby się jako «federacja» grup pierwotnych, rodzin i grup opartych na przyjaźni, zjednoczonych w narodowej wspólnocie z bardzo słabymi innymi typami więzi pomiędzy tymi dwoma poziomami". Rodzina dla jednostki jest typem „rozszerzonej osobowości”. Tylko rodzina i przyjaciel są wartościami autotelicznymi.

Z powyższego można wyciągnąć wniosek, że życie społeczne dla znacznej część społeczeństwa jest pewnego typu abstrakcją. Relacje pozarodzinne są co najwyżej tłem w życiu przeciętnego obywatela. Więzi pozarodzinne są słabe, 
nie rodzą wysokiego poczucia odpowiedzialności za działania podejmowane zbiorowo. Nowak pisał tekst o socjologicznej próżni w 1979 roku. Po ponad dwudziestu latach Janusz Czapiński uznał, że nie ma powodu, aby uważać, że punkty odniesienia dla Polaków się zmieniły. Oceniał, że Polska jest państwem bez społeczeństwa: „Próżnia między rodziną i narodem, o której w latach 70. pisał Stefan Nowak, nie zniknęła, nie wypełniła się społeczeństwem obywatelskim" (Czapiński 2006, s. 8). Podobne stanowisko zajęła Jadwiga Staniszkis w 2004 roku: „[...] w naszej tradycji społeczeństwa właściwie nie ma. Patrzymy na siebie przez pryzmat jednostki, czy podobnych jednostek posiadających ten sam instynkt dobra" (Staniszkis, Zybała 2004, s. 79). Anna Kubiak i Anita Miszalska (2004, s. 19), dokonując przeglądu literatury przedmiotu, stwierdziły, iż zdaniem wielu badaczy „[...] po roku 1989 próżnia społeczna została wypełniona tylko w niewielkim stopniu bądź że wypełniły ją układy w części instytucjonalnie niedorozwinięte lub - co gorsze - patologiczne [...]". Autorki wskazywały na proces rozpadu więzi, atomizację, a dowodem miał być spadający od początku lat dziewięćdziesiątych poziom zaufania. Jednocześnie Mikołaj Cześnik (2008, s. 19-20) podkreślał, że pojęcie socjologicznej próżni ma w polskich warunkach duży potencjał eksplanacyjny, który nie został do końca wykorzystamy w krajowej socjologii.

Warto zwrócić uwagę, że w podobny sposób o polskim społeczeństwie myślano od dawna, a wyrażano to różnie, między innymi przez podkreślanie cechy indywidualizmu Polaków czy przez wskazywanie na ich niewielkie zainteresowanie sprawami publicznymi. Oto garść przykładów. Jan E. Skiwski (1935), przedwojenny krytyk literatury i kultury, pisał, że istnieje przekonanie o tym, iż ówczesny „szary człowiek” jest „niemrawy w stosunku do spraw społecznych”. Polacy tworzą „pustynię bierności” w okresach stabilizacji politycznej, choć w okresach niebezpieczeństwa są zdolni do heroizmu. Władysław Radwan $(1938$, s. 5) dostrzegał w tym samym czasie, że w środowisku chłopskim uderzające jest „[...] przede wszystkim ograniczenie poczucia pełnej solidarności - odpowiedzialności za los człowieka do najbliższego kręgu rodziny. Wiąże się to ze sprawą rodzinnego indywidualizmu gospodarczego. Ale przekracza zakres konsekwencji układu spraw gospodarczych. W życiu wsi rodzina jest jedyną instytucją dającą oparcie jednostce, zabezpieczenie jej losu". Na podobne tendencje wskazują historycy warstwy szlacheckiej. Judyta Freylichówna $(1938$, s. 5) pisała o kulcie dla tradycji rodzinnej w środowisku szlacheckim. Aleksander Brückner (1931, s. 63), historyk kultury, sądził, że oryginalność i malowniczość czasów saskich wynikała wyłącznie $z$ intensywności życia rodzinnego i towarzyskiego, co notabene uznawał za taki sam anachronizm w Europie jak polskie wojsko lub skarb (z uwagi na ich zły stan). Z kolei Andrzej Zajączkowski twierdził, że w przeszłości Polska uchodziła bardziej za federację sąsiedztw (w domyśle rodzinnych) niż za państwo jednorodne strukturalnie. Stan taki ukształtował się zwłaszcza w okresie odbudowy kraju po zniszczeniach odniesionych w czasie potopu szwedzkiego (zob. Waśko 2006, s. 14). 
Pisał o tym również Paweł Jasienica (2007, s. 45), używając określeń „zrzeszenie sąsiedztw” oraz „Rzeczpospolita suwerennych folwarków”. Z kolei Andrzej Vincenz, między innymi znawca polskiego sarmatyzmu, twierdził, że słowo „państwo" w czasie sarmatyzmu odnoszono przede wszystkim do magnackich majątków, a później dopiero do tego, co dziś uważamy za państwo (zob. Sowa 2011). Henryk Sienkiewicz (1911) zaś w tekście pt. Dom polski oceniał, że o ile Polacy jako jednostki $z$ uwagi na ich indywidualizm doprowadzili do utraty państwa, o tyle $w$ warunkach rozbiorów rodziny jako mikrostruktury stanowią barierę przed wynarodowieniem. W rodzinach bowiem płonie ogień patriotyzmu. Postawił tezę, że żadne państwa zaborcze nie poradzą sobie z tym.

\section{SPECYFICZNY RODZAJ USPOŁECZNIENIA}

Powyższe zjawiska można wyrazić także $\mathrm{w}$ kategoriach uspołecznienia. Wiele prac badawczych wskazuje na to, że w Polsce jest ono ograniczone w znacznym stopniu do poziomu mikrostruktur społecznych, kosztem uspołecznienia do makrostruktur. Oznacza to, że znaczną część społeczeństwa charakteryzuje deficyt cech, które zazwyczaj powstają $\mathrm{w}$ procesie uspołecznienia do poziomu makrostruktur społecznych. Maria Ossowska (1970, s. 212-214) rozumie uspołecznienie jako dyspozycję do zainteresowania sprawami publicznymi, gotowość poświęcenia interesu osobistego, umiejętność współdziałania, poczucie odpowiedzialności za życie zbiorowe. Można zaryzykować tezę, iż w Polsce wciąż nie mamy do czynienia $z$ takim sposobem uspołecznienia, o jakim pisała Ossowska. Albo wciąż jest ono w trakcie transformacji. Anna Kubiak i Anita Miszalska (2004, s. 25-26, 29) piszą o familistycznym, a nie obywatelskim typie uspołecznienia w Polsce. Wskazują na to dane obrazujące niski poziom przynależności obywateli do organizacji, stowarzyszeń, partii itp.

Warto dodać, że na problem $z$ uspołecznieniem zwracano uwagę od dawna. Wielokrotnie wspominał o tym Bolesław Prus (1987, t. 1, s. 337; t. 2, s. 8-9), wprawdzie pisarz, ale z olbrzymim darem analizy i obserwacji: „Nasze społeczeństwo przedstawia się dziś nie jako organizm, nie jako sieć, z której każdy węzeł łączy się z tysiącami innych, ale - jak kupa piasku, przesypująca się między palcami”. W innym miejscu: „Społeczeństwo robiło wrażenie człowieka porąbanego na kawały: dzieliło się bowiem już nie na klasy, ale na kasty. [...] Każda kasta wyższa gardziła niższymi, każda niższa nienawidziła lub zazdrościła wyższych, wyjątkiem — chłopów, którzy nie mieli kim pogardzać i nie mieli sił nawet do nienawiści. Poczucia jedności narodowej nie było żadnego".

\section{MIĘDZY RODZINĄ A SPOŁECZEŃSTWEM}

Specyficzny profil strukturalny polskiego społeczeństwa ma wiele konsekwencji dla życia zbiorowego. Janine R. Wedel (2007) pisze o polskim społeczeństwie jako o „społeczeństwie rodzinnym”, co oznacza, że Polacy mają 
silną tendencję do skoncentrowania aktywności w obrębie rodziny, a mniejszą aktywność w ogólnej zbiorowości. Anna Giza-Poleszczuk (2009) posłużyła się terminem „społeczeństwo chałupnicze” i pisała o familizmie polskiego społeczeństwa. Jacek Tarkowski (1994a, s. 264) w odniesieniu do lat osiemdziesiątych pisał o ostrym dualizmie, czyli rozdzieleniu „świata prywatnego i publicznego, rzeczywistego i oficjalnego, «świata ludzi» i «świata instytucji»". Edmund Wnuk-Lipiński (1996, s. 238) wskazywał nawet na dwoistość postaw i wartości moralnych „W zależności od tego, czy potencjalnym partnerem jest drugi człowiek czy instytucja. Pociągało to za sobą „rozdwojenie między tym, co ludzie myślą, a tym co robią”. „Liczne badania wskazują — zdaniem Tarkowskiego (1994a, s. 265) - na wartości prywatne i prywatno-stablizacyjne jako najważniejsze w hierarchii wartości Polaków. Rodzina i życie rodzinne są wartością pojawiającą się niezmiennie na pierwszym miejscu w badaniach systemów wartości, świadomości społecznej, stylu życia. Okresy ożywienia politycznego, autentycznego uaktywnienia i uspołecznienia publicznej sfery życia (ostatnio w lalach 1980-1981) to jednocześnie okresy relatywnego zmniejszenia roli rodziny i prywatnej sfery życia w życiu codziennym Polaków, w ich aspiracjach i planach na przyszłość".

Paweł Śpiewak (2005, s. 493) potwierdza taki obraz: „Socjologowie piszą o nadwartościowywaniu więzi krewniaczych i niedowartościowywaniu więzi instytucjonalnych i kooperacyjnych". Jego zdaniem ma to wiele konsekwencji dla życia publicznego. Obywatele mają tendencję, aby stosować odmienne normy i wymagania wobec „swoich” i wobec „obcych”. „Surowo i zdecydowanie oceniamy hipokryzję i cwaniackie zachowania ludzi spoza naszego otoczenia, ale już inną taryfę stosujemy wobec «swoich», czyli członków rodziny. Im nie wolno".

Mirosława Marody(1987, s. 95) sądzi, że Polacy żyją w świecie prywatnym, gdzie dobrze sobie radza, często kierując się niesformalizowanymi regułami, oraz w świecie oficjalnym, gdzie postępują z niemal wyuczoną bezradnością. Kazimierz Z. Sowa (2012a, s. 23) ujął to jeszcze inaczej. Jego zdaniem, Polacy nie potrafią radzić sobie w sferze publicznej, „z wielkim trudem znajdują drogę do porozumienia w sprawach dotyczących dobra wspólnego”, natomiast „na ogół doskonale radzą sobie w swoich gospodarstwach domowych oraz w kręgach przyjaciół, a także w biznesie". Pisał także, że w sferze prywatnej (życiu towarzyskim, koleżeńskim) Polacy mają wiele pozytywnych cech, natomiast w życiu publicznym potrafią wznieść się na wyżyny tylko w obliczu wielkich kryzysów i zagrożeń. Najgorzej jest w codziennym życiu obywatelskim. „Do głosu dochodzą cechy ujemne, destrukcyjne, niesprzyjające rozwijaniu i umacnianiu wspólnoty obywatelskiej" (Sowa 2012a, s. 110).

Z kolei Edmund Wnuk-Lipiński (1996, s. 238) pisał o tętniących życiem mikrostrukturach społecznych, które funkcjonują poza formalnymi instytucjami publicznymi. Jedną z konsekwencji było powstanie w okresie PRL silnego podziału na „my” (wąskie grupy) i „oni” (przedstawiciele formalnego sys- 
temu, ale także ci poza danym kręgiem rodzinno-towarzyskim). Przetrwało to w znacznym stopniu również po 1990 roku w nowej postaci. Janusz Czapiński dostrzegł, że w miejsce więzi makrospołecznych wśród Polaków ukształtował się model zaradnego indywidualizmu. „Żyjemy w kraju coraz bardziej efektywnych jednostek i niezmiennie nieefektywnej wspólnoty" (Czapiński 2013, s. 308).

Z kolei Piotr Gliński (2007, s. 126) podkreślał, że społeczeństwo polskie jest „mozaiką wielu enklaw”. Jego zdaniem, „mnogość enklaw jest dowodem na słabość polskiego społeczeństwa obywatelskiego i jego makrostruktur. Enklawowość oznacza bowiem, słabość pozytywnych, poziomych więzi międzyludzkich i międzygrupowych, oznacza niski poziom otwartości na innych, wielość izolowanych tożsamości społecznych. Pociąga to za sobą deficyt inkluzyjności, dialogu, sieciowości w relacjach społecznych.

Według Jacka Tarkowskiego (1994b) specyficzna struktura polskiego społeczeństwa (federacja małych i silnie zintegrowanych wewnętrznie grup) sprawia, iż występuje w nim silnie syndrom „amoralnego familizmu”. Dochodzi również do kształtowania się $\mathrm{w}$ wielu przypadkach i sferach relacji patron-klient (relacja rozumiana jako wzajemna, często niesymetryczna zależność między jednostkami pozostającymi w bliskich relacjach). Jak pisze Tarkowski (1994b, s. 41), relacje klientystyczne występują we wszystkich społeczeństwach, ponieważ dla obu stron tej relacji mają pewien specyficzny urok, ale $\mathrm{w}$ Polsce można mówić o ich znacznym zasięgu. Wynika to choćby $\mathrm{z}$ istniejących nierówności ekonomicznych, szybkich przemian czy z trudności dostępu do pewnych dóbr, które stają się osiągalne dzięki interwencji „odpowiednich” osób. Ponadto w Polsce wyjątkowo długo trwały typowe relacje feudalnej zależności (senior-wasal). Zdaniem Antoniego Mączaka (2000, s. 30), w XVI-XVIII wieku klientelizm był istotą ówczesnego systemu władzy. Gdy na Zachodzie od tego czasu jego zasięg szybko kurczył się, w Polsce pozostawał silnie zakorzeniony. W okresie PRL, a także później, klientelizm został niejako sfunkcjonalizowany, warunkował działanie wielu istotnych mechanizmów państwa i procesów decyzyjnych.

\section{DALSZE SKUTKI SOCJOLOGICZNEJ PRÓŻNI}

Wiele skutków opisanych zjawisk można dziś dostrzec w sferze funkcjonowania państwa i sposobie realizacji polityk publicznych. Zdaniem Jerzego Hausnera (2009, s. 59), można mówić o swoistej instytucjonalizacji nieodpowiedzialności za dobro zbiorowości. Dotyczy to zarówno obywateli, jak i grup społecznych. Wyrazem tego jest skłonność obywateli do przerzucania odpowiedzialności za sprawy publiczne na państwo, skłonność do prywatyzacji zysków i upubliczniania prywatnych strat. Przejawy takiej postawy wśród klasy politycznej to kolonizacja administracji państwa, jej obojętność na patologie życia publicznego, zgoda na korupcję. Z kolei wśród urzędników wyrazem nieodpo- 
wiedzialności jest uznaniowość w procesie decyzyjnym, niska jakość decyzji, niska sprawność czy nieprzejrzystość tworzonych przez nich procedur. Według Wiktora Osiatyńskiego (2004, s. 120): „nastąpiło przystosowanie do nieodpowiedzialności, co spowodowało zatracenie zdolności przystosowania”. Edmund Mokrzycki (2001, s. 13) uważał, że postawy klasy politycznej sprawiły, iż nastąpiło skompromitowanie samego pojęcia odpowiedzialności za kraj. W wyniku tego ukształtował się swoisty etos bezwzględnej i brutalnej walki „o swoje”. Jednocześnie niemożliwe stało się realizowanie polityki publicznej $\mathrm{w}$ dłuższym horyzoncie czasu ( $z$ uwagi na koncentrację na bieżących partykularnych zyskach).

Zjawisko próżni socjologicznej można powiązać także ze stanem opisywanym jako „miękkie państwo” (Hausner 2009). Oznacza to dość specyficzne funkcjonowanie państwa. Z jednej strony jego instytucje ograniczają aktywność obywateli, a z drugiej nie jest ono w stanie wypełniać zadań tradycyjnie przypisywanych tym instytucjom. Nie jest w stanie wytwarzać usług publicznych na znośnym poziomie, a zatem nie jest $\mathrm{w}$ stanie realizować wielu polityk publicznych. Nie radzi sobie z obroną interesu publicznego wobec partykularyzmów grupowych. Następuje także podział sektora publicznego na strefy wpływu (Jasiecki 2013, s. 212). Instytucje państwa stają się niekiedy częścią sieci, które są zorganizowane w celu realizacji grupowych interesów. Jeśli patrzymy przez pryzmat doświadczeń historycznych Polaków, to taki model państwa nie może uchodzić za nic szczególnie dziwnego.

Można przywołać pogląd Adama Podgóreckiego o występowaniu w Polsce skłonności do powstawania „brudnych wspólnot”. Gdy aktorzy społeczni wchodzą w sytuację działania publicznego, mają skłonność do formowania grup, których współpraca często służy łamaniu prawa w celu uzyskaniu partykularnych korzyści. Tworzą sieci wzajemnych powiązań, opartych na lojalnościach, które są „cementowane za pomocą więzów rodzinnych, wzajemnie świadczonych usług, wspólnictwa $\mathrm{w}$ dokonywaniu rozmaitych [...] naruszeń prawa, świadomości rozmaitych postępków nagannych, partycypacji we wzajemnie korzystnych nieformalnościach, możliwości wzajemnego szantażu" (Podgórecki 1976, s. 17). Pojęcie brudnej wspólnoty podchwyciła Janine R. Wedel (2003, s. 139-159), polsko-amerykańska socjolożka, która popularyzuje je $\mathrm{w}$ języku angielskim jako dirty togetherness. Na poziomie jednostkowych relacji powstawanie brudnych wspólnot było strategią działania wobec problemu niedostatku $\mathrm{w}$ zaopatrzeniu $\mathrm{w}$ okresie PRL. Ludzie uzyskiwali dostęp do wielu dóbr w wyniku wymiany tego, do czego wzajemnie mieli dostęp. Powstające sieci przekonfigurowywały sposób funkcjonowania oficjalnych systemów dystrybucji ówczesnych dóbr. Nieformalne relacje powstawały również na szczeblach instytucjonalnych czy w sferze procedur ustanawianych przez biurokrację. Następowała personalizacja relacji instytucjonalnych. Krystalizowały się ośrodki wpływu nabierające charakteru sieci (kliki), wyspecjalizowane w korzystaniu z publicznych zasobów bez wypracowywania proporcjonalnej 
wartości dla społeczeństwa. W ostatnim okresie widoczny jest wzrost zleceń publicznych, które urzędy państwowe przekazywały z tzw. wolnej ręki (Majszyk, Wikariak 2014).

Janusz Czapiński wskazuje, że opisane tendencje w społeczeństwie mają wpływ na skalę rozwoju gospodarczego. Umożliwiają one rozwój ekonomiczny, ale tylko do pewnego poziomu. Czapiński zaproponował pojęcie „molekularny rozwój" na oznaczenie rozwoju opartego na aktywności i przedsiębiorczości w mikrostrukturach, czyli kręgach rodzinno-koleżeńskich. W Polsce tego typu rozwój ma miejsce od 1990 roku, ale od pewnego czasu można dostrzec jego bariery. Ogranicza on bowiem rozwój w przestrzeni publicznej, zwłaszcza rozbudowę infrastruktury transportowej, usług publicznych, a są to w obecnej dobie kluczowe czynniki umożliwiające zaawansowany rozwój. "Jesteśmy w fazie rozwoju molekularnego, charakterystycznego dla krajów słabo rozwiniętych w opozycji do rozwoju wspólnotowego, charakterystycznego dla krajów wysoko rozwiniętych. [...] Żyjemy w kraju coraz bardziej efektywnych jednostek i niezmiennie nieefektywnej wspólnoty" (Czapiński 2013, s. 308).

Historycy dość powszechnie wskazują, że państwo w Polsce od dawna nie miało statusu podobnego jak instytucja państwa na Zachodzie. Nie gwarantowało zazwyczaj obywatelom bezpieczeństwa, warunków do rozwoju osobistego czy lokalnego. Andrzej Wyczański pisze, że państwo w XVIII wieku nie zapewniało przyzwoitego sądownictwa (brak egzekucji wyroków), przyzwoicie działających organów policyjno-porządkowych (zabezpieczenie życia, majątku). Istniało wówczas przekonanie, że tylko solidarność grupowa, w tym sąsiedzka czy lokalna może dać ochronę i szansę na przyzwoite życie. „Płaszczyznę wspólną stanowiły bliskie kontakty towarzyskie [...] poczucie solidarności w stosunku do obcych czy innych ziem, wreszcie sejmik, gdzie spotykała się szlachta, uchwalała postanowienia porządkowe, podatki, często ich rozkład, czasami nawet zaciągała milicję powiatową, gdy wymagało tego niebezpieczeństwo" (Wyczański 1965, s. 399).

W naukach społecznych w Polsce prawdopodobnie nieprzypadkowo powstał silny nurt badań skoncentrowanych na sferze nieformalnych relacji. Wskazuje się, że często nie ma wyraźnej granicy między działaniami grup nieformalnych i działaniami instytucji państwa, śledzi się mechanizmy naruszające interes publiczny, powstawanie nieformalnych grup interesów, które wykorzystują swoje usytuowanie do pomnażania partykularnych korzyści kosztem innych. Andrzej Zybertowicz (2005) pisze, że tak zwane antyrozwojowe grupy interesu mają silny wpływ na decyzje państwa w sprawach publicznych. Często działają one w sposób nieformalny na styku różnych sektorów i instytucji. Jerzy Hausner (2007) pisze o tworzeniu się branżowych sieci wpływu na zachowanie pozycji przestarzałych struktur gospodarczych, na przykład w przemyśle ciężkim. Również Jacek Sroka (2000) wskazuje, że w Polsce mamy do czynienia $z$ łatwym zawiązywaniem koalicji interesów i formowaniem niezbyt transparentnych reguł wplywu. Pisze o kartelach dystrybutywnych. Ma to tworzyć 
zagrożenia dla przejrzystości procesu decyzyjnego. Z kolei Jadwiga Staniszkis (2001) sygnalizowała powstawanie superkorporacji na styku administracji i wybranych stowarzyszeń, przedstawicielstw pracodawców i innych.

\section{W ŚWIETLE POJĘĆ POLITYKI PUBLICZNEJ}

Do tej pory była mowa o generalnych konsekwencjach wytworzenia się specyficznego typu relacji społecznych dla życia publicznego w Polsce, takich jak: niezdolność do uformowania państwa jako względnie neutralnego arbitra zdolnego do rozwiązywania wielu typów problemów zbiorowych, skłonność do działań nieformalnych czy konfrontacyjność $\mathrm{w}$ relacjach między aktorami działań publicznych. Teraz chciałbym wskazać te konsekwencje w języku typowym dla polityk publicznych jako specyficznej dyscypliny wiedzy. Przedstawiam główne składowe tak zwanego klasycznego cyklu (koła) polityk/działań publicznych (zob. zestawienie na s. 42-43). Opisuje on caly proces funkcjonowania polityki publicznej: od fazy definiowania problemu, który wymaga rozwiązania, po ocenę rezultatów tego rozwiązania (Górniak 2008, s. 62). W nauce o polityce publicznej istnieje niemal odwieczna dyskusja o walorach poznawczych tego cyklu (Zybała 2013a). Nie będę przedstawiał stosowanych w niej argumentów, zrobię tylko zastrzeżenie, że jest on daleko idącym uproszczeniem realnej złożoności polityki publicznej, ale pozostaje niezwykle użyteczny w wyjaśnianiu jej kluczowych elementów.

Cykl ten składa się z następujących faz (etapów) czy składników:

- diagnozowanie wyłaniającego się problemu publicznego,

- budowanie alternatywnych koncepcji rozwiązania problemu (aby wybrać optymalna),

- ewaluacja ex ante koncepcji rozwiązania problemu,

- wdrażanie przyjętego rozwiązania i realizacji (implementacja),

- ewaluacja ex post działań zrealizowanych na podstawie wybranej koncepcji rozwiązania problemu.

Zamierzam przedstawić pewne rudymentarne cechy polityki publicznej $\mathrm{w}$ Polsce $\mathrm{w}$ poszczególnych jej fazach. Wynikają one $\mathrm{z}$ analizowanych wcześniej czynników kulturowych. W pierwszej fazie działania publicznego (identyfikowanie problemów) widoczne są cechy, które można określić jako skłonność do „prywatyzowania” problemów zbiorowych. Interesariusze polityk mają skłonność do postrzegania jako „prywatne” wielu typów problemów w krajach Zachodu uznawanych zwykle za publiczne (zbiorowe). Wydaje się, że nawet bezrobocie często jest u nas uznawane za problem samych bezrobotnych, a nie problem zbiorowy, który wynika z wadliwych rozwiązań strukturalnych przyjętych w gospodarce. Świadczy o tym relatywnie niskie zainteresowanie bezrobociem (poza wyjątkowymi sytuacjami, zwykle kryzysami) i jego skutkami społecznymi wśród klasy politycznej, a nawet $\mathrm{w}$ mediach. Również problem biedy często uznaje się za problem biednych, a problem mieszkaniowy jest 
problemem tych, którzy nie zdobyli dla siebie dachu nad głową. Takie przykłady można łatwo mnożyć.

„Prywatyzacja problemów” ma dalsze konsekwencje. Otóż interesariusze polityk wykazują niską skłonność do angażowania się $\mathrm{w}$ profesjonalne diagnozowanie problemów publicznych, małą chęć ich głębszego zrozumienia, a także udziału w procesie deliberacji nad problemami zbiorowymi (Włodarczyk 1998). Widoczna jest również niezdolność do formułowania adekwatnej agendy problemów publicznych. Pociąga to za sobą kwestie strukturalne niedostatek profesjonalnych instytucji analitycznych, brak troski o wypracowywanie nowoczesnych metod analizy problemów, brak skłonności do dialogu badawczego ( $z$ myślą o wypracowaniu konsensusu dotyczącego metod badania problemów). Można wprawdzie dostrzec, że generowany jest coraz większy zasób wiedzy, ale jednocześnie widoczny jest problem struktury tej wiedzy i jej użyteczności w procesie tworzenia i realizowania polityki publicznej: „dane te są rozproszone, nie są rzetelnie oceniane i właściwie prezentowane” (Jelonek, Keler, Worek 2010, s. 50).

Spójrzmy teraz na fazę formułowania polityki publicznej albo innymi słowy fazę wypracowania koncepcji działania (w tym koncepcji reformy w danej polityce, na przykład zdrowia czy edukacji). Na tym poziomie podejmowane są decyzje o przyjęciu określonej koncepcji rozwiązania danego problemu. W Polsce interesariusze wykazują niewielką skłonność do sięgania po koncepcje polityki publicznej opartej na dowodach (evidence-based policy). W ograniczonej skali zatem podstawą podejmowanych decyzji jest zobiektywizowana wiedza. Finalna koncepcja rozwiązania (policy option) często wybierana jest na podstawie kalkulacji kosztów dla finansów publicznych (tanie rozwiązania, często nieefektywne). Często też jest to wynik kalkulacji politycznych (układ sił wśród grup interesów). Problem ten nie został dostatecznie przeanalizowany, ale istnieją badania, które potwierdzają tezy mówiące o słabym zaangażowaniu administracji publicznej w analizy eksperckie (zob. np. Domaradzka, Krzewski, Ledzion, Olejniczak, Widła 2010, s. 51). Podobne wnioski wypływają z analizy kilkunastu polityk publicznych (fazy ich formułowania) (Zybała 2014). Interesariusze polityk w szczególności wskazywali na brak analiz dotyczących oceny ryzyk związanych z podejmowanymi działaniami. Tymczasem ryzyko stało się na świecie niezwykle nośną kategorią analiz.

Cały kompleks konsekwencji ma specyficzne scentralizowanie procesu decyzyjnego i tendencja władzy do jednostronnego działania na etapie formułowania polityk (Zybała 2013b). Wytworzył się szczególny typ zarządzania publicznego (public governance), rozumianego jako sieć relacji między aktorami działań publicznych, a zwłaszcza relacji między rządzącymi a podmiotami pozarządowymi. W Polsce ukształtował się model etatystyczny, a jego cechą szczególną jest właśnie jednostronność działania rządzących, którzy często są przekonani, że posiadają wystarczające zasoby, by w pojedynkę skutecznie rozwiązywać problemy zbiorowe (Zybała 2013b). Wyrazem swoistego etatyzmu jest to, że 
rządzący posługują się zwykle instrumentami legislacyjnymi uznawanymi za najbardziej inwazyjne wobec innych interesariuszy. W znacznie mniejszej skali stosowane są instrumenty „miękkie”, które mają za zadanie katalizowanie zachowań interesariuszy i korespondują z celami publicznymi. Wskazuje to na znaczące dystanse społeczne dzielące interesariuszy.

Konsekwencją etatyzmu jest niski poziom poczucia podmiotowości wielu interesariuszy działań publicznych. W 2013 roku tylko niespełna jedna piąta Polaków była przekonana, że ma jakiś wpływ na sprawy kraju (w tym 5\% respondentów odczuwało, że ma duży wpływ), a 79\% uważało, że nie ma żadnej możliwości wpływania na bieg spraw publicznych (CBOS 2013). Prawdopodobnie $z$ tego wynika niewielki udział obywateli i zorganizowanych grup w konsultacjach społecznych nad projektami aktów prawnych potrzebnych do realizacji polityk publicznych (SMG/KRC 2011).

Podsumowując ten wątek odwołam się do wyników badań własnych (zrealizowanych wroku 2014), które wykazały, że formułowanie polityk jest procesem o znacznym ryzyku niepowodzenia (zob. Zybała 2014). Do sformułowania polityki dochodzi bowiem zazwyczaj w dość złożonych okolicznościach, przede wszystkim wówczas gdy dostrzegalny jest już kryzys, zwłaszcza w postaci zagrożenia dla stabilności finansów w danej polityce, czy na znaczną skalę pojawia się niezdolność do zaspokajania potrzeb społecznych. Często oznacza to, że rządzący podejmują działania pośpieszne, nie poprzedzone właściwym przebadaniem problemu i wywołaniem deliberacji publicznych $\mathrm{w}$ gronie interesariuszy.

Sformułowanie polityki jako koncepcji rozwiązania problemu uwarunkowane jest ponadto występowaniem dwóch innych czynników (okoliczności). Otóż interesariusze (zwłaszcza rządzący) podejmują działania dopiero wtedy, gdy są przekonani, że do uzyskania zamierzonego rezultatu planowanych działań wystarczą im narzędzia legislacyjne (regulacje prawne) i nie muszą stosować zaawansowanych procedur partycypacji z udziałem innych interesariuszy. Ostatnim czynnikiem istotnym $\mathrm{w}$ procesie formułowania polityki jest fakt wyłonienia się dominującego interesariusza, który uzyskuje decydujący wpływ na proces decyzyjny (zazwyczaj są to rządzący) ${ }^{1}$.

Powyższy obraz nie wydaje się korzystny z punktu widzenia sprawności państwa w zakresie rozwiązywania problemów zbiorowych i efektywności działania. Najmniej korzystną cechą jest to, że decydenci podejmują interwencje publiczne głównie w sytuacji znaczącego kryzysu i zagrożenia dla stabilności. Innymi słowy, dominuje podejście reaktywne do projektowania interwencji publicznych, a nie proaktywne, a więc wyprzedzające moment, w którym dochodzi do zaostrzenia problemu (Parsons 2001, s.186). Badania pokazały również, że

${ }^{1} \mathrm{~W}$ tym zestawieniu pomijam sytuację, w której dana polityka publiczna powstaje na skutek dyrektyw unijnych albo innych wymogów związanych z dostosowaniem się do międzynarodowych polityk. 
formułowaniu polityk nie towarzyszy kumulowanie wiedzy analitycznej. Badani pracownicy administracji publicznej stwierdzali raczej, że wiedzy wytwarzano dużo i w adekwatnej skali, natomiast eksperci pozarządowi często czuli niedosyt w tym zakresie.

Przechodzę teraz do analizy kolejnej fazy funkcjonowania polityki publicznej, czyli etapu, na którym powinno dojść do ewaluowania rezultatów uzyskanych w wyniku działań publicznych ${ }^{2}$. W krajach najwyżej rozwiniętych opracowywanie raportów $z$ badań ewaluacyjnych uznawane jest za standard. Zapewnia bowiem dostęp do zobiektywizowanych danych, które umożliwiają formułowanie ocen, ale także rekomendacji do wykorzystania w kolejnym cyklu działania. Ewaluacja traktowana jest jako mechanizm wzajemnego uczenia się $\mathrm{w}$ gronie interesariuszy (Olejniczak 2008, s. 22). Tymczasem w polskich realiach ewaluacja nie zapuściła głębokich korzeni. Raporty ewaluacyjne wykonywane są zasadniczo dla działań finansowanych ze źródeł Unii Europejskiej, ponieważ instytucje europejskie ich wymagają. Natomiast w odniesieniu do działań finansowanych ze środków krajowych politycy i urzędnicy generalnie nie dążą do opracowywania takich dokumentów. Odczuwa się brak dobrej infrastruktury niezbędnej do wykonywania ewaluacji. Niedostatki opracowań ewaluacyjnych można uznać za jeden $z$ najpoważniejszych powodów niskiej jakości działań publicznych (Reichardt 2011; Górniak, Mazur 2010). Nie dochodzi bowiem do wypracowania wiedzy zwrotnej obrazującej rezultaty działań publicznych.

Dalsza faza działania publicznego to etap wdrażania rozwiązania (implementacja). W literaturze przedmiotu opisuje się przede wszystkim dwa modele wdrażania (implementacji) — odgórny i oddolny (czasami spotykany trzeci model uznany jest za hybrydowy) (Zybała 2013a). W Polsce obserwujemy ten pierwszy - ma miejsce administracyjny styl wdrażania projektów działań (np. reform). Rządzący działają w sposób jednostronny, z małym wykorzystaniem mechanizmów partycypacji. Wyraża się to między innymi w posługiwaniu się instrumentami legislacji jako głównym narzędziem działania (ustawy, rozporządzenia) kosztem stosowania tak zwanych "miękkich” instrumentów (perswazja, bodźce, dostarczanie interesariuszom wiedzy i informacji itp.).

Ponadto $\mathrm{w}$ sferze wdrażania widoczna jest konfrontacyjność relacji między aktorami działań publicznych, co ogranicza skalę pogłębionej współpracy (a często jest ona niezbędna, aby działania publiczne mogły przynieść dobry rezultat). Na czoło wysuwają się konflikty i nieumiejętność efektywnego ich łagodzenia. Wiele jest przypadków podejmowania działań bez choćby ramowego konsensusu z kluczowymi interesariuszami, bez których działania nie mogą przynieść dobrych rezultatów. Ma to silny związek z niską zdolnością do stanowienia uniwersalnych (trwałych) reguł działania, czytelnych dla interesariuszy i otoczenia. Powszechne natomiast jest niskie poczucie odpowiedzialności za

\footnotetext{
2 Uwzględniam tu ewaluowanie ex ante i ex post.
} 
rezultaty działań, ich sukces z punktu widzenia celów publicznych. Dominują jednostronne dążenia do korzyści grupowych.

Przykładów problemów specyficznych dla etapu wdrażania działań dostarczają choćby główne reformy w politykach publicznych ostatnich lat. Większość $z$ nich realizowano $z$ wielkim trudem, jak choćby reformy z przełomu wieków (tzw. cztery reformy rządu AWS/UW). Część z nich dość szybko musiała zostać przeformułowana, ponieważ konsekwencje, jakie wywołały, zagrażały stabilności finansów publicznych (zawłaszcza reforma emerytalna). Nawet działania bardziej doraźne formułowane i realizowane są z trudem. Dowodem na to mogą być perypetie $z$ tworzeniem podstaw prawnych ich realizacji. Często bywa tak, że szereg aktów prawnych wymaga nowelizacji, zanim zostaną wdrożone w życie (np. reforma polityki „odpadowej”, polityki społecznej w przypadku wprowadzenia asystentów rodzinnych). Wiele aktów prawnych jest nowelizowanych dziesiątki razy w krótkim czasie (Goetz, Zubek 2005). Wprowadza to chaos, a interesariuszy zmusza do przyjęcia krótkoterminowych strategii działania obliczonych na szybkie korzyści.

Próbowałem tu uzasadnić tezę, że typ relacji i więzi społecznych występujących w Polsce jest źródłem wielu istotnych kłopotów z realizowaniem działań publicznych. Z całą pewnością są one widoczne w wielu działaniach. Także tych, powiedzmy, niskiego kalibru, w których chodzi o zrealizowanie, wydawałoby się, prostych celów, jak wybudowanie drogi. Jednak szczególnych kłopotów przysparzają działania strategiczne państwa, zwłaszcza te, których celem jest na przykład określenie modelu gospodarki, wywołanie innowacyjności w sektorze publicznym i prywatnym, dopasowanie systemu edukacji do wyzwań cywilizacyjnych, spójność społeczna itp. Trudności wynikają z tego, że te działania wymagają właśnie cech, których brakuje w społeczeństwie, czyli umiejętności współpracy wielu interesariuszy, mobilizowania komplementarnych zasobów (ludzkich, analitycznych, finansowych itp.), zdolności do tworzenia złożonych koncepcji działań i ich realizowania w długim horyzoncie czasowym.

Problemy z jakością działania publicznego mają charakter kulturowy, co starałem się wykazać. Nie jest zatem dziwne, że występują one od wielu dziesiątków lat, a nawet wieków. Porażkę odnieśli reformatorzy, którzy próbowali zapobiec rozbiorom państwa pod koniec XVIII wieku. Z trudem przeprowadzono reformy w okresie międzywojennym (np. reforma rolna, oświaty). W latach siedemdziesiątych ubiegłego wieku Jan Szczepański (1973, s. 111) oceniał, że ówczesne reformy nie przynosiły zakładanych rezultatów. Wskazywał na różnorakie przyczyny, na to, że brakowało potencjału do badania problemów publicznych i tworzenia koncepcji ich rozwiązań. Narzekał także na sposób reformowania. Wskazywał, że reformy u nas często są rozumiane nazbyt technicznie. 
Wpływ czynników kulturowych na charakterystykę polityki publicznej w poszczególnych fazach jej tworzenia i funkcjonowania

\begin{tabular}{|c|c|c|}
\hline \begin{tabular}{|c|} 
Fazy \\
w funkcjonowaniu \\
polityki publicznej \\
(według modelu \\
fazowego)
\end{tabular} & Cechy działania publicznego & $\begin{array}{c}\text { Ryzyka (zagrożenia) } \\
\text { dla efektywności działań publicznych }\end{array}$ \\
\hline $\begin{array}{l}\text { Definiowanie } \\
\text { wyłaniającego się } \\
\text { problemu } \\
\text { publicznego }\end{array}$ & $\begin{array}{l}\text { - identyfikowanie głównie bezpo- } \\
\text { średnich zagrożeń dla stabilności } \\
\text { państwa (finanse, prawo, bezpie- } \\
\text { czeństwo energetyczne itp.) } \\
\text { - uznawanie większości problemów } \\
\text { zbiorowych za problemy de facto } \\
\text { prywatne } \\
\text { - niskie zainteresowanie problemami } \\
\text { zbiorowymi } \\
\text { - konfrontacyjność aktorów w pre- } \\
\text { zentowaniu racji pokazujących zna- } \\
\text { czenie analizowanego problemu }\end{array}$ & $\begin{array}{l}\text { - niedostateczna diagnoza i słabe zro- } \\
\text { - bumienie problemów } \\
\text { fliktu interesów w wyniku słabego } \\
\text { procesu deliberacji i analizy } \\
\text { - niedostatek profesjonalnych insty- } \\
\text { tucji analitycznych } \\
\text { - brak skłonności do dialogu badaw- } \\
\text { czego (uzgadniania priorytetów ba- } \\
\text { dawczych) } \\
\text { - brak nowoczesnych metod analizy } \\
\text { problemów }\end{array}$ \\
\hline $\begin{array}{l}\text { Formułowanie } \\
\text { koncepcji działania } \\
\text { (m.in. poprzez } \\
\text { badanie } \\
\text { alternatywnych } \\
\text { koncepcji } \\
\text { rozwiązań } \\
\text { problemu } \\
\text { zbiorowego) }\end{array}$ & $\begin{array}{l}\text { - przyjęcie określonego rozwiązania } \\
\text { (policy option) wynika bardziej z kal- } \\
\text { kulacji kosztów dla bieżących fi- } \\
\text { nansów publicznych oraz z kalkula- } \\
\text { cji politycznych niż z dowodów na } \\
\text { efektywność } \\
\text { - powstawanie nieformalnych relacji } \\
\text { między interesariuszami (enklawy) } \\
\text { - konfrontacyjność w przetargach in- } \\
\text { teresów } \\
\text { - niskie poczucie odpowiedzialności } \\
\text { za rezultaty działań publicznych } \\
\text { - nieadekwatna agenda problemów } \\
\text { do rozwiązania }\end{array}$ & $\begin{array}{l}\text { - ograniczona skala badań i analiz } \\
\text { eksperckich, wytworzonych dowo- } \\
\text { dów } \\
\text { - niedostatek uniwersalnych reguł } \\
\text { tworzenia rozwiązań dla proble- } \\
\text { mów } \\
\text { - niskie poczucie podmiotowości } \\
\text { wielu interesariuszy } \\
\text { - scentralizowanie procesu decyzyj- } \\
\text { nego } \\
\text { - formułowanie polityki publicznej } \\
\text { w krótkim horyzoncie czasu (z uwa- } \\
\text { gi na koncentrację na bieżących par- } \\
\text { tykularnych korzyściach) } \\
\text { - niskie umiejętności projektowania } \\
\text { działań o charakterze strategicz- } \\
\text { nym (z klarowanymi i realistycz- } \\
\text { nymi priorytetami) }\end{array}$ \\
\hline Ewaluacja ex ante & $\begin{array}{l}\text { - ewaluacja przeprowadzana w gro- } \\
\text { nie głównie udziałowców politycz- } \\
\text { nych (komisje sejmowe, ewentual- } \\
\text { nie podgrupy partyjne) } \\
\text { - brak skłonności do uczenia się z ra- } \\
\text { portów ewaluacyjnych i wykorzy- } \\
\text { stywania zobiektywizowanej wie- } \\
\text { dzy w nich zawartej }\end{array}$ & $\begin{array}{l}\text { - brak zobiektywizowanych metod } \\
\text { ewaluacji } \\
\text { - niska skłonność do wykorzystania } \\
\text { danych z ewaluacji do poprawiania } \\
\text { jakości działań publicznych }\end{array}$ \\
\hline
\end{tabular}


Ciag dalszy tabeli z poprzedniej strony

\begin{tabular}{|c|c|c|}
\hline $\begin{array}{c}\text { Fazy } \\
\text { w funkcjonowaniu } \\
\text { polityki publicznej } \\
\text { (według modelu } \\
\text { fazowego) }\end{array}$ & Cechy działania publicznego & $\begin{array}{c}\text { Ryzyka (zagrożenia) } \\
\text { dla efektywności działań publicznych }\end{array}$ \\
\hline $\begin{array}{l}\text { Wdrażanie } \\
\text { przyjętego } \\
\text { rozwiązania } \\
\text { i realizacji }\end{array}$ & $\begin{array}{l}\text { - konfrontacyjność wśród interesa- } \\
\text { riuszy } \\
\text { - brak właściwego zakresu współ- } \\
\text { pracy } \\
\text { - niskie poczucie odpowiedzialności } \\
\text { za rezultaty działań publicznych } \\
\text { - nieumiejętność efektywnego łago- } \\
\text { dzenia konfliktów interesów } \\
\text { - nieumiejętność tworzenia trwałych } \\
\text { norm i reguł działania publicznego }\end{array}$ & $\begin{array}{l}\text { - administracyjny styl wdrażania re- } \\
\text { form, nowych koncepcji } \\
\text { - dominacja przepisów prawa jako in- } \\
\text { strument działania (ustawy, rozpo- } \\
\text { rządzenia) } \\
\text { - krótkie cykle działań (brak umiejęt- } \\
\text { ności łączenia działań w szersze pa- } \\
\text { kiety) } \\
\text { - niski poziom poczucia współwła- } \\
\text { sności wprowadzonych regulacji } \\
\text { - ryzyko wielu niezamierzonych kon- } \\
\text { sekwencje wdrożonych działań }\end{array}$ \\
\hline Ewaluacja ex post & $\begin{array}{l}\text { - brak kultury wzajemnego uczenia } \\
\text { się wśród aktów } \\
\text { - brak skłonności do ewaluacji zreali- } \\
\text { zowanych interwencji/działań pu- } \\
\text { blicznych } \\
\text { - niski poziom umiejętności stosowa- } \\
\text { nia ewaluacji }\end{array}$ & $\begin{array}{l}\text { - ewaluacja sprowadzona głównie do } \\
\text { publikowania sprawozdań z prze- } \\
\text { prowadzonych działań wykonywa- } \\
\text { nych przez urzędy } \\
\text { - mało niezależnych ewaluacji (poza } \\
\text { działaniami finansowanymi ze środ- } \\
\text { ków UE) }\end{array}$ \\
\hline
\end{tabular}

Źródło: opracowanie własne.

\section{BIBLIOGRAFIA}

Adolino Jessica R., Blake Charles H., 2001, Comparing Public Policies: Issues and Choices in Six Industrialized Countries, CQPress, Washington.

Brückner Aleksander, 1931, Dzieje kultury polskiej, t. 3: Czasy nowsze do roku 1831 r., Krakowska Spółka Wydawnicza, Kraków.

Castles Francis G., 1998, Comparative Public Policy: Patterns of Post-War Transformation, Edward Elgar Publishing. Northampton, Mass.

CBOS, 2013, Poczucie wptywu na sprawy publiczne, oprac. Krzysztof Pankowski, Centrum Badania Opinii Społecznej, BS/121/2013.

Czapiński Janusz, 2006, Polska - państwo bez spoteczeństwa, „Nauka”, nr 1.

Czapiński Janusz, 2013, Kapitał społeczny, w: Janusz Czapiński, Tomasz Panek (red.), Diagnoza społeczna 2013. Warunki i jakość życia Polaków, Rada Monitoringu Społecznego, Warszawa.

Czapiński Janusz, Panek Tomasz (red.), 2009, Diagnoza spoteczna 2009. Warunki ijakość życia Polaków, Rada Monitoringu Społecznego, Warszawa.

Czapiński Janusz, Panek Tomasz (red.), 2013, Diagnoza społeczna 2013. Warunki i jakość życia Polaków, Rada Monitoringu Społecznego, Warszawa.

Cześnik Mikołaj, 2008, Próżnia socjologiczna a demokracja — przykład postkomunistycznej Polski, „Kultura i Społeczeństwo", nr 4.

Domaradzka Anna, Krzewski Andrzej, Ledzion Bartosz, Olejniczak Karol, Widła Łukasz (red.), 2010, Polskie ministerstwa jako organizacje uczace się, Euroreg, Warszawa. 
Friszke Andrzej, 1989, O kształt niepodległej, Biblioteka Więzi, Warszawa.

Freylichówna Judyta, 1938, Ideat wychowawczy szlachty polskiej w XVI i początku XVII wieku, Nasza Księgania, Warszawa.

Giza-Poleszczuk Anna, 2009, Rodzina i system społeczny, w: Mirosława Marody (red.), Wymiary życia społecznego. Polska na przetomie XX i XXI wieku, Scholar, Warszawa.

Gliński Piotr, 2007, Enklawowość polskiego spoteczeństwa obywatelskiego, w: Leszek Gołdyka, Irena Machaj (red.), Enklawy życia społecznego, Wydawnictwo Naukowe Uniwersytetu Szczecińskiego, Szczecin.

Gliński Piotr, 2009, Enklawy kulturowo-akcjologiczne we wspótczesnej Polsce — próba wstępnego opisu, w: Leszek Gołdyka, Irena Machaj (red.), Enklawy życia społecznego: kontynuacje, Wydawnictwo Naukowe Uniwersytetu Szczecińskiego, Szczecin.

Goetz Klaus H., Zubek Radosław, 2005, Stanowienie prawa w Polsce. Reguly legislacyjne a jakość ustawodawstwa, Sprawne Państwo. Program Ernst\&Young, Warszawa.

Gorzelak Grzegorz, 2000, Zewnętrzna interwencja jako czynnik rozwoju lokalnego (na przyktadzie Programu Inicjatyw Lokalnych), „Studia Regionalne i Lokalne”, nr 3(3).

Górniak Jarosław, 2008, Sprawne państwo - cykle tworzenia i oceniania polityk/programów publicznych, „Dialog. Pismo Dialogu Społecznego”, nr 4.

Górniak Jarosław, Mazur Stanisław (red.), 2010, Polityki publiczne oparte na dowodach i ich zastosowanie do rynku pracy, Pracodawcy RP, Warszawa.

Granovetter Mark, 1973, The Strength of Weak Ties, „American Journal of Sociology”, t. 78, s. 1360-1380 .

Hausner Jerzy, 2007, Pętle rozwoju. O polityce gospodarczej lat 2001-2005, Scholar, Warszawa.

Hausner Jerzy, 2009, Z „Kuźnicy”, z rządu i spoza..., Universitas, Kraków.

Hoppe Robert, 2007, Apllied Cultural Theory: Took for Policy Analysis, w: Frank Fisher, Gerald J. Miller, Mara S. Sidney (red.), Handbook of Public Policy Analysis: Theory, Politics and Methods, CRC Press-Taylor\&Francis Group, Boca Raton.

Jasiecki Krzysztof, 2013, Kapitalizm po polsku. Między modernizacja a peryferiami Unii Europejskiej, Wydawnictwo IFiS PAN, Warszawa.

Jasienica Paweł, 2007, Polska anarchia, Prószyński S-ka, Warszawa.

Jelonek Magdalena, Keler Karolina, Worek Barbara, 2010, Dane - ich gromadzenie, integracja i jakość, w: Jarosław Górniak, Stanisław Mazur (red.), W kierunku polityki rynku pracy opartej na dowodach, Pracodawcy RP, Warszawa.

Kalberg Stephen, 1980, Max Weber's Types of Rationality: Cornerstones for the Analysis of Rationalization Process in History, „American Journal of Sociology”, t. 85, s. 1145-1179.

Kojder Andrzej, 2008, Korupcja i przekonania moralne Polaków, w: Janusz Mariański, Leon Smyczek (red.), Wartości, postawy i więzi moralne $w$ zmieniajacym się społeczeństwie, Wydawnictwo WAM-Polskie Towarzystwo Socjologiczne, Kraków.

Kolarska-Bobińska Lena, 2000, Wstęp, w: Lena Kolarska-Bobińska (red.), Cztery reformy. Od koncepcji do realizacji, Oficyna Naukowa-Instytut Spraw Publicznych, Warszawa.

Krzemiński Ireneusz, 2005, IV RP — rozczarowanie i nadzieja, „Ius et Lex”, nr 1.

Kubiak Anna, Miszalska Anita, 2004, Czy nowa próżnia spoteczna, czyli o stanie więzi społecznej w III Rzeczypospolitej, „Kultura i Społeczeństwo”, nr 2.

Majszyk Konrad, Wikariak Sławomir, 2014, Rynek zamówień wychodzi z cienia, „Dziennik. Gazeta Prawna", 3 czerwca.

Marody Mirosława, 1987, Antynomie zbiorowej podświadomości, „Studia Socjologiczne”, nr 2.

Mączak Antoni, 2000, Klientela. Nieformalne systemy władzy w Polsce i Europie XVI-XVIII w., Semper, Warszawa.

Mokrzycki Edmund, 2001, Bilans niesentymentalny, Wydawnictwo IFiS PAN, Warszawa.

Nowak Stefan, 1979, System wartości społeczeństwa polskiego, „Studia Socjologiczne”, nr 4. 
Nowak Stefan, 2009, O Polsce i Polakach. Prace rozproszone 1958-1989, Wydawnictwo Uniwersytetu Warszawskiego, Warszawa.

Olejniczak Karol, Ferry Martin, 2008, Ewaluacja w praktyce sektora publicznego, w: Bożena Pietras-Goc (red.), Ewaluacja jako standard zarządzania w sektorze publicznym, Wyższa Szkoła Europejska im. ks. Józefa Tischnera, Kraków.

Olejniczak Karol, 2008, Wprowadzenie do ewaluacji, w: Karol Olejniczak, Marek Kozak, Bartosz Ledzion (red.), Teoria i praktyka ewaluacji interwencji publicznych, Wydawnictwa Akademickie i Profesjonalne-Akademia Leona Koźmińskiego, Warszawa.

Osiatyński Wiktor, 2004, Rzeczpospolita obywateli, Rosner\&Wspólnicy, Warszawa.

Ossowska Maria, 1970, Normy moralne. Próba systematyzacji, Państwowe Wydawnictwo Naukowe, Warszawa.

Parsons Wayne, 2001, Public Policy: An Introduction to the Theory and Practice of Policy Analysis, Edward Elgar, Aldershot.

Podgórecki Adam, 1976, Kontrola społeczna trzeciego stopnia, „Prace IPSiR UW”, t. 1, Wydawnictwo Uniwersytetu Warszawskiego, Warszawa.

Podgórecki Adam, 1995, Spoteczeństwo polskie, tłum. Zbigniew Pucek, Wydawnictwo Wyższej Szkoły Pedagogicznej, Rzeszów.

Polanyi Karl, 2010, Wielka transformacja. Polityczne i ekonomiczne źródła naszych czasów, tłum. Maria Zawadzka, Wydawnictwo Naukowe PWN, Warszawa.

Prus Bolesław, 1987, Kroniki. Wybór, PIW, Warszawa.

Radwan Władysław, 1938, Psychika chtopa i jej źródta, „Kultura i Wychowanie”, nr 1.

Reichardt Iwona, 2011, Ewaluacja jako narzędzie analizy polityk publicznych, „Zarządzanie Publiczne”. Zeszyty Naukowe Instytutu Spraw Publicznych Uniwersytetu Jagiellońskiego, nr 1(13).

Richardson Jeremy, Gustaffson Gunnel, Jordan Grant, 1982, The Concept of Policy Style, w: Jeremy Richardson (red.), Policy Styles in Western Europe, Allen\&Unwin, London-Boston.

Rychard Andrzej, 2006, Kapitat społeczny a instytucje. Wstępne rozważania, w: Henryk Domański, Antonina Ostrowska, Paweł B. Sztabiński (red.), W środku Europy? Wyniki Europejskiego Sondażu Spolecznego, Wydawnictwo IFIS PAN, Warszawa.

Sienkiewicz Henryk, 1911, Dom polski i jego znaczenie, „Przegląd Powszechny”, nr 109.

Skiwski Jan E., 1935, Chory optymizm i zdrowy pesymizm, „Tygodnik Ilustrowany”.

SMG/KRC, 2011, Raport końcowy z badań efektywności mechanizmów konsultacji spotecznych, Poland Media, Pracownia Badań i Innowacji Społecznych Stocznia, Warszawa.

Sowa Jan, 2011, Fantomowe ciało króla. Peryferyjne zmagania z nowoczesna formą, Universitas, Kraków.

Sowa Kazimierz Z., 2012a, Obywatel w państwie. Kilka uwag o typach ładu zbiorowego i spoteczeństwie polskim, „Państwo i Społeczeństwo”, t. 12, nr 1.

Sowa Kazimierz Z., 2012b, Szkice o sferze publicznej i społeczeństwie obywatelskim, Wydawnictwo Uniwersytetu Jagiellońskiego, Kraków.

Sroka Jacek, 2000, Europejskie stosunki przemystowe w perspektywie porównawczej, Wydawnictwo Uniwersytetu Wrocławskiego, Wrocław.

Staniszkis Jadwiga, 2001, Postkomunizm, słowo/obraz terytoria, Gdańsk.

Staniszkis Jadwiga, Zybała Andrzej, 2004, Szanse Polski. Nasze możliwości rozwoju w obecnym świecie, Rectus, Komorów.

Stowarzyszenie Klon/Jawor (oprac.), 2009, Zakorzenienie i uspołecznienie działań organizacji pozarządowych, Ministerstwo Pracy i Polityki Społecznej Departament Pożytku Publicznego, Warszawa.

Swedlow Brendon, 2002, Toward Cultural Analysis in Policy Analysis: Picking Up Where Aaron Wildavsky Left Off, ,Journal of Comparative Policy Analysis", t. 4, nr 3.

Szczepański Jan, 1973, Refleksje nad oświata, Państwowy Instytut Wydawniczy, Warszawa.

Szczepański Jan, 1999, Reformy, rewolucje, transformacje, Wydawnictwo IFiS PAN, Warszawa.

Śpiewak Paweł, 2005, Polskie spoteczeństwo w opiniach socjologów, „Ius et Lex”, nr 1. 
Tarkowski Jacek, 1994a, Socjologia świata polityki, t. 1: Wtadza i społeczeństwo w systemie autorytarnym, Instytut Studiów Politycznych PAN, Warszawa.

Tarkowski Jacek, 1994b, Socjologia świata polityki, t. 2: Patroni i klienci, Instytut Studiów Politycznych PAN, Warszawa.

Waśko Andrzej, 2006, O modernizacji Polski w epoce kryzysu suwerenności państwa (1698-1795), w: Jacek Kloczkowski, Michał Szułdrzyński (red.), Drogi do nowoczesności. Idea modernizacji w polskiej myśli politycznej, Ośrodek Myśli Politycznej-Wyższa Szkoła Europejska im. ks. Józefa Tischnera, Kraków.

Wedel Janine R., 2003, Dirty Togetherness: Institutional Nomads, Networks, and the State-Private Interface in Central and Eastern Europe and the Former Soviet Union, „Polish Sociological Review”, nr 2.

Wedel Janine R., 2007, Prywatna Polska, Trio, Warszawa.

Włodarczyk Cezary, 1998, Reforma opieki zdrowotnej w Polsce. Studium polityki zdrowotnej, Uniwersyteckie Wydawnictwo Medyczne Vesalius, Kraków.

Wnuk-Lipiński Edmund, 1996, Demokratyczna rekonstrukcja. Z socjologii radykalnej zmiany spotecznej, Wydawnictwo Naukowe PWN, Warszawa.

Wyczański Andrzej, 1965, Polska rzeczpospolita szlachecka 1454-1764, Państwowe Wydawnictwo Naukowe, Warszawa.

Zybała Andrzej, 2013a, Trzeci sektor jako aktor w politykach publicznych, „Trzeci Sektor”, nr 30/2.

Zybała Andrzej, 2013b, Polityki publiczne wobec wzorców zarzadzania publicznego, „Zarządzanie Publiczne", nr 4(26).

Zybała Andrzej, 2013c, Państwo i spoteczeństwo w działaniu, Difin, Warszawa.

Zybała Andrzej, 2014, Prawidłowości w procesie formułowania polityk publicznych $w$ Polsce. Raport $z$ badań, Instytut Polityk Publicznych-Collegium Civitas, Warszawa.

Zybertowicz Andrzej, 2005, Anti-Development Interest Groups, „Polish Sociological Review”, nr 1(149).

\section{PUBLIC POLICY IN A SOCIOLOGICAL VACUUM}

\section{Sum mary}

The author presents the socio-cultural framework of the process of formulating and implementing public policies/activities (including their analysis and evaluation). He gives grounds for the idea that socio-cultural factors have a deciding influence on the present low level of effectiveness of public activities/policies in Poland (although structural and economic factors also have an impact). Reference to the phenomenon of a 'sociological vacuum' and its consequences (such as minute interest in public issues, and lack of responsibility for public activities and for meeting the needs of others) is important in the analysis. The author points to the historical origins of the phenomenon and refers to earlier studies. He claims this vacuum is responsible for the clumsiness characterizing present attempts to deal with various collective problems-particularly the more complicated ones, whose resolution would require considerable social capital, analytical capacity, and the connection of social and economic resources. In his opinion, public politics in Poland could remain for a long time in its present shape-characterized by the creation of legal regulations without much use of analytics, and by unilateral actions of the political class and the strongest interest groups.

\section{Key words/słowa kluczowe}

public policy / polityka publiczna; implementation / implementacja; culture / kultura; social ties / więzi społeczne; contemporary Polish society / współczesne społeczeństwo polskie 